INTERNATIONAL JOURNAL OF RESEARCHES IN BIOSCIENCES, AGRICULTURE AND TECHNOLOGY (C) VISHWASHANTI MULTIPURPOSE SOCIETY (Global Peace Multipurpose Society) R. No. MH-659/13(N) www.vmsindia.org

\title{
EFFECT OF ACORUS CALAMUS EXTRACT ON GROWTH AND DEVELOPMENT OF CORCYRA CEPHALONICA (ST.)
}

\author{
Sandhya Jadhav \\ Research Laboratoy, Department of Zoology, New Arts Commerce and Science College, Ahmednagar \\ drsandhyajadhav@gmail.com
}

\begin{abstract}
:
The naturally occurring allilochemics play a promising role in insect control by deterring insect feeding by their effects as insect growth regulators, as antihormones or as insecticides. Effect of Acorus calamus rhizome extracts on reproductive ability i.e. fecundity was reduced at more than $42.158 \%$. There is reduction in hatching percentage also. It may be due to reduced juvenile hormone titre which resulted inhibition of egg development. It changes the hormone pool hence disturbs the egg maturation process. It indicates that Acorus calamus rhizome extract would make a substantial contribution to the recent efforts towards a safer and more effective pest control programme.
\end{abstract}

Keywords: Acorus calamus, growth and development Corcyra cephalonica.

\section{Introduction}

In insects corpus allatum $(\mathrm{CA})$ secretes juvenile hormone $(\mathrm{JH})$ which plays an important role in insect growth metamorphosis and reproduction. Further the research work continued and centred round such aspect as implication of CA hormone on the life cycle and morphogenesis of external and internal structures. This aspect was considered for hormonal control of insect development. (William1967) and the term was coined as "Third generation pesticides" The need for such pesticides was due to growing awareness of environmental hazards from synthetic insecticides and associated problems of pest resistance to insecticides pest regurgence. So there is urge for safe, effective and economical insecticide. The plant kingdom can provide such chemicals with diverse biological activities. The plant isolates have activities of entomological interest and have attracted attention of many workers. In present investigation effect of Acorus calamus rhizome extract on fecundity of Corcyra cephalonica (st.).

\section{Materials and Methods}

The biological material for the present study i. e. Corcyra cephalonica (st.) larvae from the laboratory maintained culture were taken for the experimentation. A group of $5^{\text {th }}$ instar larvae was selected and treated with Acorus calamus rhizome extract as $5 \mu 1$ of sublethal dose in acetone applied topically on the abdomen of the test larva with the help of Hamilton microliter syringe. The dose applied was $26.36 \%$. Controls were treated with $5 \mu 1$ of acetone only. They were kept in the batches of ten larvae in each Petri dish. Three replica were maintained. They were allowed to feed on the food. So as to record average fecundity, the adults developed from the treated larvae were collected. The male and female moths were selected and paired separately and kept in separate specimen tubes for egg laying. So as to study the effect of plant extracts on reproductive potential of Corcyra cephalonica and to estimate the number of eggs laid in each treatment they were counted daily till the female died. It was replicated for five times. For percent hatchability a random sample of twenty eggs was taken from each replica and placed on a cello tape to prevent the escape of newly hatched larvae. At the same time incubation period of eggs was also recorded for each treatment. All the results were subjected to analysis of variance.

\section{Results and Discussion}

The reproductive ability of the moths emerging from larvae treated with Acorus calamus rhizome extract reduced greatly. There was great reduction in egg production per female. It was $70.0 \%$. The hatchability percentage was affected due to the seed extract (Table).

The results obtained from the extract treated larvae on fecundity show that the Corcyra was significantly affected. The reproductive ability i.e. fecundity was greatly reduced at more than $40.08 \%$. There is reduction in hatching percentage also. It may be due to reduced juvenile hormone titre which resulted inhibition of egg development. It changes the hormone pool hence disturbs the egg maturation process. These results agree with the previous work. (Patterson,1978), that the effect of larval nutrition on egg production was by injected proteins particularly organic nitrogen. Proteins are well known for growth, 
survival and fecundity of insects (Slansky, 1982). Patel et.al. (1997) reported significant inhibition of Aphid fecundity due to Lantana camera, Azadirachta indica, Ipomea cornea and Theventia nerifolia. Sundarraj et.al (1995) reported considerable reductions in egg production of Taragama sivia due to neem seed kernel powder extract. Shanthi and Logiswaran (1996) found the decreased fecundity in Sitotroga due to extracts of Eucalyptus. Khanal et.al (1992), Tiwari (1993),Prasad et.al.(1993) reported efficicancy of Acorus calamus as pest protectant.It indicates that Acorus calamus rhizome extract would make a substantial contribution to the recent efforts towards a safer and more effective pest control programme. It is also indicated that chemicals from plant source have provided interesting, challenging and explorable research to entomologists for discovering newer allochemics of plant origin.

Table - Effect of Acorus calamus rhizome extract on development and fecundity of Corcyra cephalonica (st.)

\begin{tabular}{|l|l|l|}
\hline & Control & $\begin{array}{l}\text { Acorus } \\
\text { calamus } \\
\text { rhizome } \\
\text { Extract treated }\end{array}$ \\
\hline $\begin{array}{l}\text { Larval } \\
\text { period }\end{array}$ & $10.2 \pm 1.12$ & $\begin{array}{l}12.8 \pm 1.47^{*} \\
(-25.49)\end{array}$ \\
\hline $\begin{array}{l}\text { Pupation } \\
\text { period }\end{array}$ & $7.2 \pm 0.92$ & $\begin{array}{l}9.3 \pm 0.75^{*} \\
(-29.166)\end{array}$ \\
\hline $\begin{array}{l}\text { Adult } \\
\text { emergence }\end{array}$ & $96.4 \pm 3.48$ & $\begin{array}{l}70.5 \pm 6.52 \\
(26.86)\end{array}$ \\
\hline $\begin{array}{l}\text { Eggs laid / } \\
\text { female }\end{array}$ & $159.4 \pm 5.32$ & $\begin{array}{l}92.2^{*} \pm 2.42 \\
(42.158)\end{array}$ \\
\hline Hatchability \% & $92.52 \pm 6.47$ & $\begin{array}{l}70.0^{*} \pm 1.48^{*} \\
(24.34)\end{array}$ \\
\hline $\begin{array}{l}\text { Incubation } \\
\text { period(days) }\end{array}$ & $5.9 \pm 0.85$ & $\begin{array}{l}6.1 \pm 0.22 \\
(-3.38)\end{array}$ \\
\hline
\end{tabular}

Each value is the mean of three observations \pm . Values in parentheses indicate \% variation over control.

Values are significant at $\mathrm{P}<1$ *

The incubation period of eggs laid by female of Acorus calamus rhizome extract treated larvae was not affected.

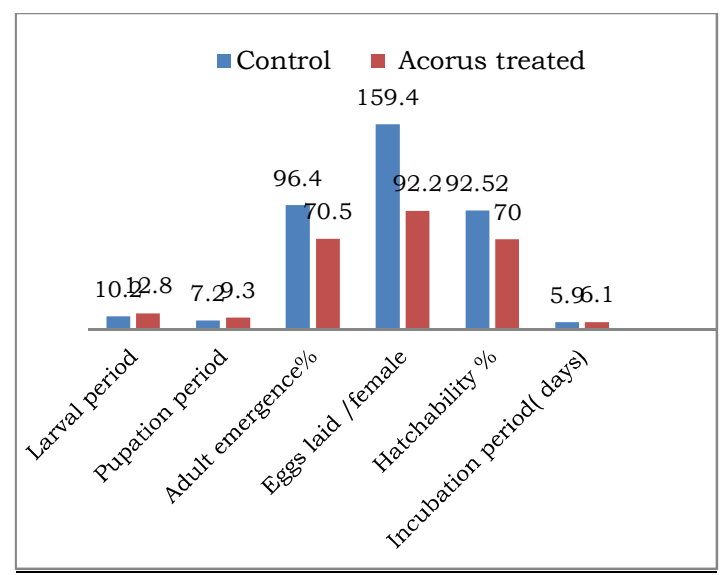

Figure- Effect of Acorus calamus rhizome extract on development \& fecundity of Corcyra cephalonica (st.)

\section{References}

Khanal et.al (1992),

Maheshwari H.K. and Dwivedi S.C. (1996) “ Evaluation of botanicals for the management of Tribolium castaneum (Coleoptera: Tenebrionidae.)" Insect Environment 2(3) :72-73

Patel J.J., Patel,N.C.,Jayani D.B.Patel J.R. and Patel B.D.(1997) "Bioefficicacy of synthetic and botanical insecticides for controlling pod borer ( Helicoverpa armigera) and pod $\mathrm{fl}$ (Melanagromyza obtuse) infesting vegetable purpose pigeon pea (Cajanus cajan)." Indian Journal of Agricultural Sciences. 67(3):117-119.

Patterson, J.W. (1978) : The effect of larval nutrition on egg production in Rhodnius prolizus. J.Insect Physiol.25:311-314.

Prasad et.al. (1993) Shanthi M.J. and Logiswaran G (1996) : " Efficacy of Petroleum ether extract of plant parts on the biology of Sitotroga cerealella . Madras Agricultural Journal 83 (1) : 53-56.

Slansky, F.Jr.(1982) : “ Insect nutrition,an

Sundarraj R., Murugeson S., Ahmed S.I. (1995): Differential impact of NSKP extract on nutrition and reproduction of Targama siva Lefebvere ( Lepidoptera : Lasiocampidae ). Entomon 20 (3/4) 257-261)

Tiwari (1993),

Williams C.M. (1967) : Third generation pesticides." Scientific American 7 :2483 -2487. 